\title{
FACILITIES \&OPERATIONS
}

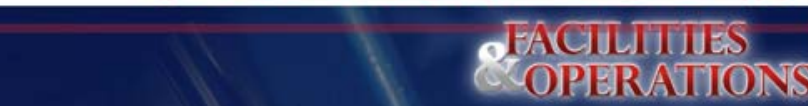

\section{Building Arc Flash Investigation Team Report}

INVESTIGATION

TEAM REPORT
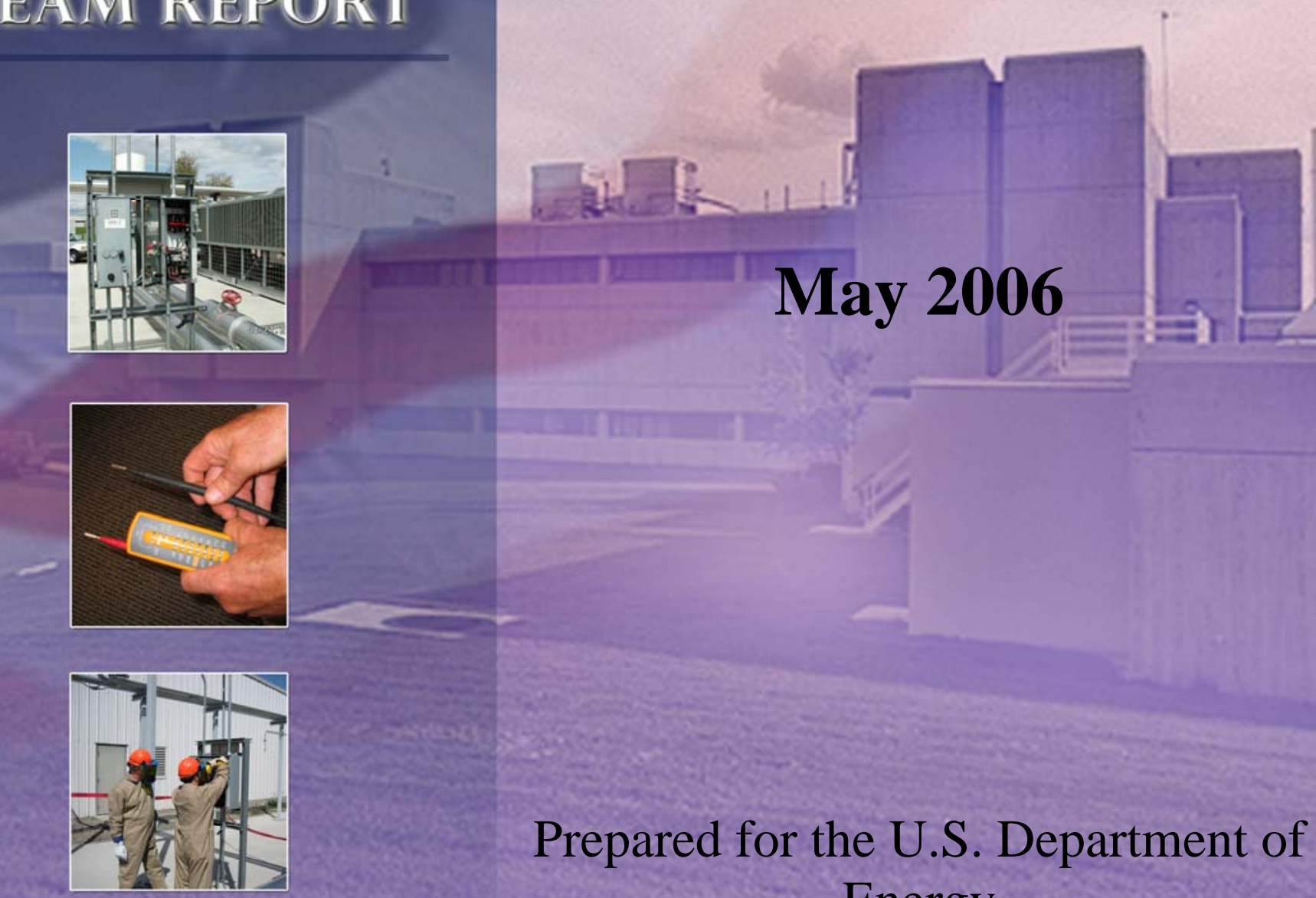

Prepared for the U.S. Department of Energy

Pacific Northwest under Contract DE-AC05-

National Laboratory 76RL01830

Operated by Battelle for the

U.S. Department of Energy 


\title{
DISCLAIMER
}

This report was prepared as an account of work sponsored by an agency of the United States Government. Neither the United States Government nor any agency thereof, nor Battelle Memorial Institute, nor any of their employees, makes any warranty, express or implied, or assumes any

legal liability or responsibility for the accuracy, completeness, or usefulness of any information, apparatus, product, or process disclosed, or represents that its use would not infringe privately owned rights. Reference herein to any specific commercial product, process, or service by trade name, trademark, manufacturer, or otherwise does not necessarily constitute or imply its endorsement, recommendation, or favoring by the United States Government or any agency thereof, or Battelle Memorial Institute. The views and opinions of authors expressed herein do not necessarily state or reflect those of the United States Government or any agency thereof.

\author{
PACIFIC NORTHWEST NATIONAL LABORATORY \\ operated by \\ BATTELLE \\ for the \\ UNITED STATES DEPARTMENT OF ENERGY \\ under Contract DE-AC05-76RL01830
}

Printed in the United States of America

\author{
Available to DOE and DOE contractors from the \\ Office of Scientific and Technical Information, \\ P.O. Box 62, Oak Ridge, TN 37831-0062; \\ ph: (865) 576-8401 \\ fax: (865) $576-5728$ \\ email: reports@adonis.osti.gov
}

Available to the public from the National Technical Information Service, U.S. Department of Commerce, 5285 Port Royal Rd., Springfield, VA 22161 ph: (800) 553-6847 fax: (703) 605-6900

email: orders@ntis.fedworld.gov online ordering: http://www.ntis.gov/ordering.htm 
FACILITIES

QYOPERATIONS

INVESTIGATION TEAM REPORT

\section{Building Arc Flash Investigation Team Report}

May 2006

\section{Prepared for the U.S. Department of Energy under Contract DE-AC05-76RL01830}

Prepared By:

$$
\begin{aligned}
& \text { Reed Sharp, FøD, Technical } \\
& \text { Operations and Assurance }
\end{aligned}
$$

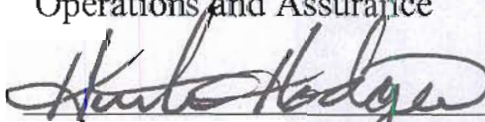

Hurtis Hodges, FOD, haintenance

And Fabrication Services Manager

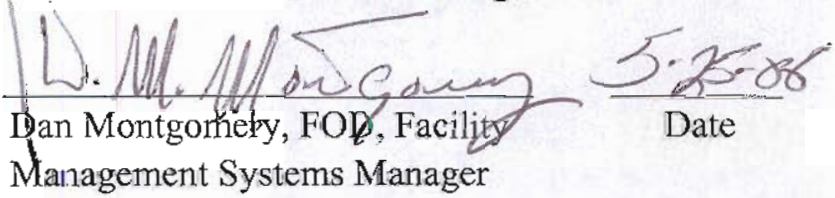

Concurred/

Submitted By:

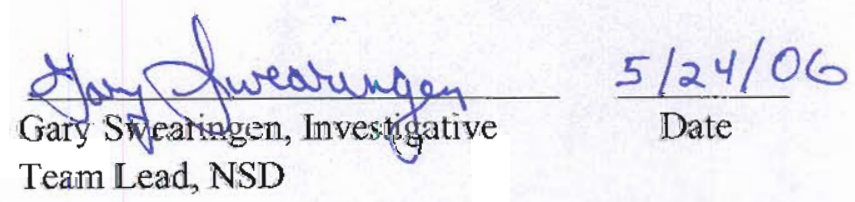

Approved By.

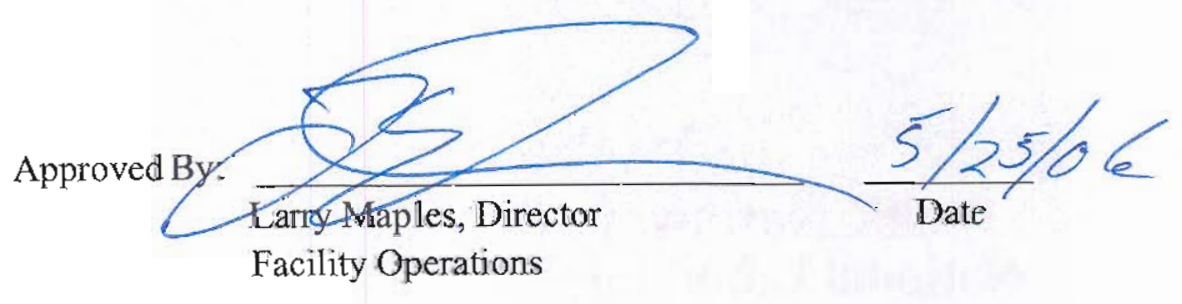

Facility Operations 
FACILITIES

QOPERATIONS

INVESTIGATION

TEAM REPORT

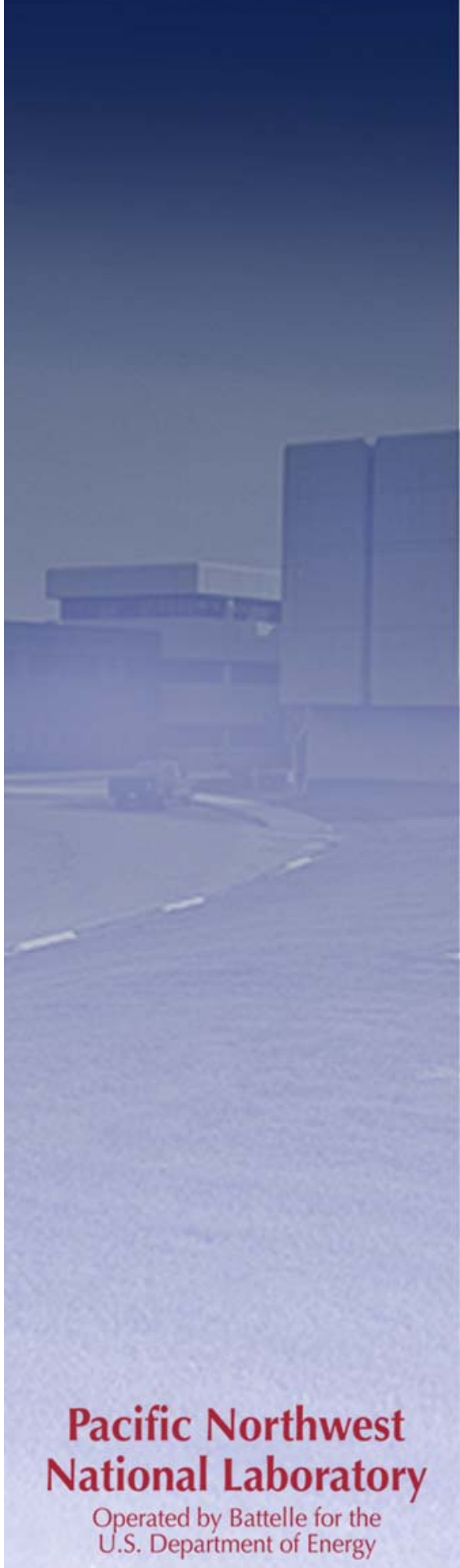

This page intentionally left blank 
FACILITIES QXOPERATIONS

INVESTIGATION TEAM REPORT

\section{Executive Summary}

On Friday, April 21, 2006, a PNNL electrician was performing repair of an electrical system for the 331 Building chilled water pump (CHWP) \#2, when an electrical arc flash occurred inside a $480 \mathrm{~V}$ combination motor starter. The electrician was taken to the on-site medical provider for evaluation and was released for return to work without restriction. The electrician was not shocked, but did receive a minor, superficial (first degree) burn on the left wrist.

To troubleshoot and repair the 331 Building CHWP \#2, work planning actions were taken, including isolation of the electrical source and use of lockout/tagout (LOTO) for hazardous energy control. Workers involved in the repair activity were aware of the electrical hazards associated with this type of work and took precautions, as identified in existing procedures, to create a safe work environment. The LOTO activities included Safe-Condition and Safe-to-Work checks of the deenergized condition of the combination motor starter. Following verification of the supposed de-energized condition, the workers doffed their PPE and an arc flash occurred during performance of the work.

Post-event inspection of the chilled water system components identified the labels for the breakers supplying power to CHWP \# 2 and CHWP \#1 were reversed. The energized state of the combination motor starter due to the wrong system configuration was not detected during verification of de-energized state by the workers. The event investigation identified three credible failure modes for why the workers failed to detect the presence of electrical energy on the line side of the combination motor starter disconnect.

PNNL's procedures for commissioning new or modified systems need to be revised to include verification of proper labeling. In addition LOTO Safe-Condition/Safe-to-Work verification procedures need to be revised to provide additional requirements and guidance.

Pacific Northwest National Laboratory

Operated by Battelle for the U.S. Department of Energy 
FACILITIES QOPERATIONS INVESTIGATION TEAM REPORT

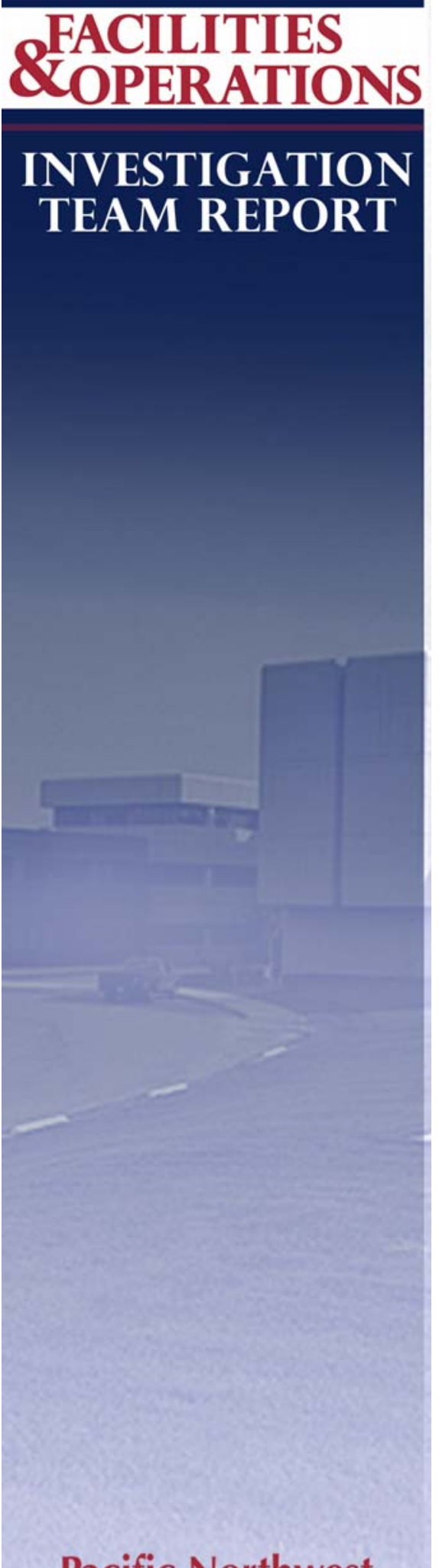

Pacific Northwest National Laboratory

Operated by Battelle for the U.S. Department of Energy

\section{Table of Contents}

EXECUTIVE SUMMARY 5

$\begin{array}{ll}\text { 1.0 EVENT DESCRIPTION } & 7\end{array}$

2.0 BACKGROUND 9

WORK ACTIVITY

331 BUILDING CHILLED WATER SYSTEM HISTORY 12

3.0 CAUSAL FACTORS

DiRECT CAUSE

ROOT CAUSES 13

CONTRIBUTING CAUSES $\quad 14$

4.0 CONCLUSIONS \& RECOMMENDATIONS

RECOMMENDATIONS: 15

OPPORTUNITIES FOR IMPROVEMENT: 16

APPENDIX A: TEAM CHARTER \& TEAM MEMBERS 17

APPENDIX B: METHODOLOGY $\quad 19$

APPENDIX C: INTERVIEWS CONDUCTED 20

APPENDIX D: EVENT TIMELINE

APPENDIX E: BARRIERS ANALYSIS 26 


\subsection{Event Description}

On Thursday, April 20, 2006, around 1800 hours the 331 Building chilled water pump (CHWP) \#2 failed to run. The operator noted in the shift log "...When the breaker to the \#2 pump was opened, the \#1 pump/chiller shut down. Alarms from the wet lab started to come in, when the breaker to the \#2 pump was closed the \#1 pump/chiller came back on line ?...”. The power operator notified the building engineer of this condition and was instructed to submit a service request to troubleshoot and repair CHWP \#2. On Friday, April 21, 2006, after approval of the Service Request work scope, an electrician was dispatched to perform any necessary repairs. During performance of the troubleshooting and associated repairs, an electrical arc flash occurred inside the combination motor starter for CHWP \#2. The electrician was taken to the on-site medical provider for evaluation and was subsequently released to return to work without restriction.

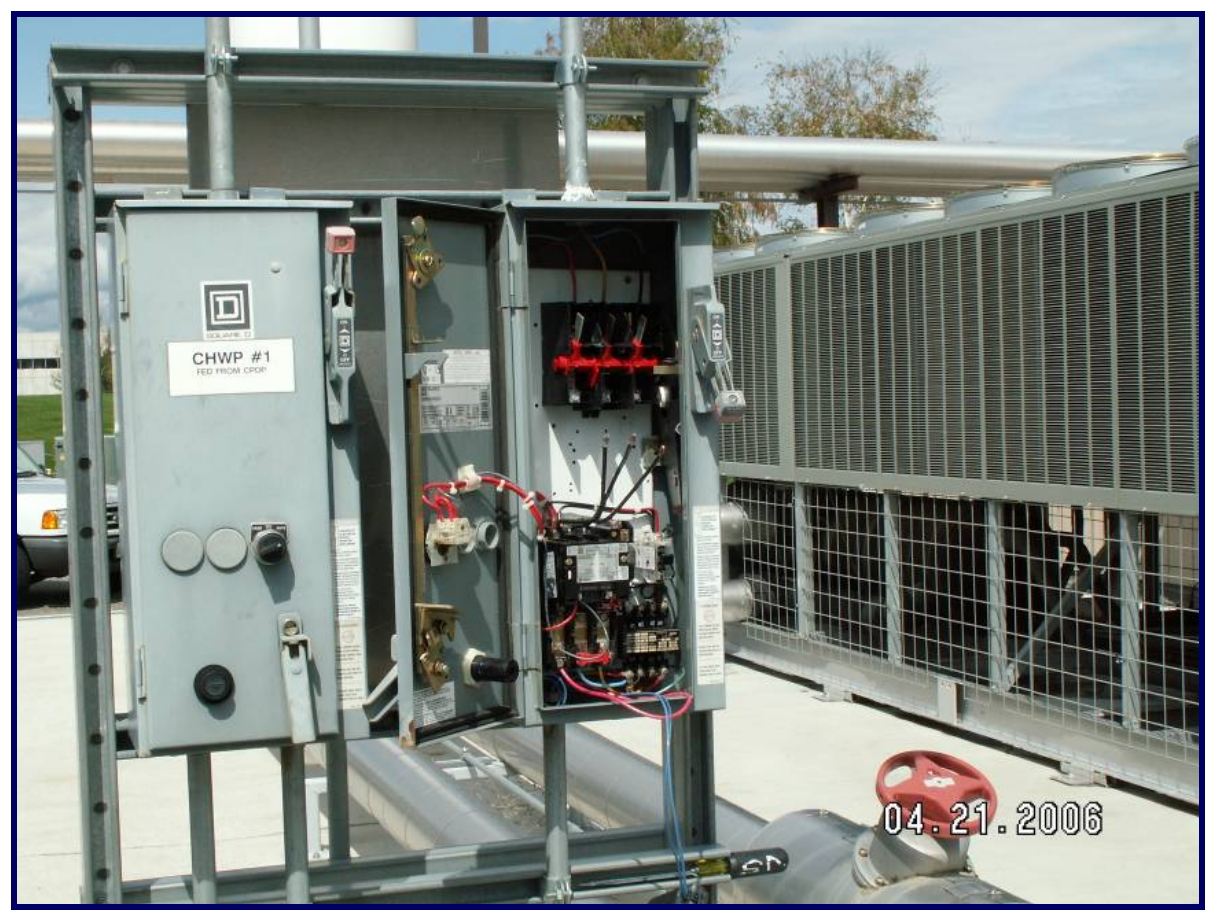

Figure 1.1. 331 Building Chilled Water Pump \#2 Electrical Panel

In preparation for CHWP \#2 troubleshooting and repair, steps were taken to isolate the electrical energy source by opening the breaker labeled CHWP \#2, performing Safe-Condition and Safeto-Work checks of the de-energized condition, and applying LOTO on the system in accordance with approved procedures before work began. Appropriate Personal Protective Equipment (PPE) consisting of fire retardant coveralls, safety glasses, face shield, ear plugs, voltage rated gloves and leather work gloves was worn throughout the lockout/tagout process, including the performance of Safe-Condition and Safe-to-Work checks (Checks). Once the de-energized verification checks were completed ( $\sim 900$ hrs), the workers doffed their PPE and began troubleshooting and repair. 
In the course of troubleshooting, a failed control transformer was diagnosed as the likely cause of the CHWP \#2 failure. A replacement control transformer was obtained and repair activities began for changing out the failed control transformer. Later during the process of installing the new control transformer, an arc flash occurred. ( $1320 \mathrm{hrs})$. The cause of the arc flash was determined to be associated with the installation of the new control transformer and repositioning the combination motor starter internal mounting plate, which also has the disconnect line-side phase lugs attached to it. During manipulation of the mounting plate, the line-side $\mathrm{C}$ phase conductor came out of its lug and contacted the B Phase lug resulting in an arc flash.

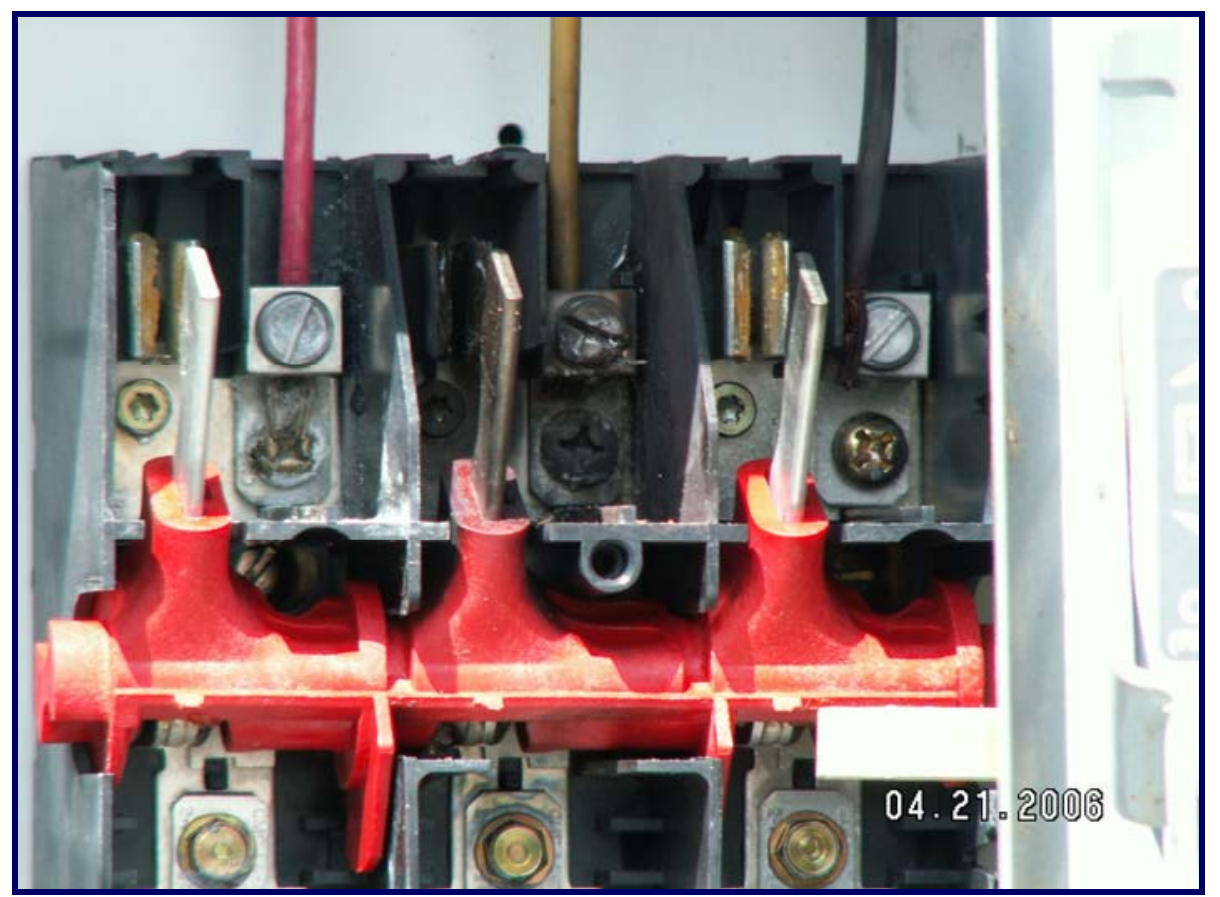

Figure 1.2. C and B Phase Conductors where arc flash occurred

The electrician performing the work did not contact any energized components, but received a minor, superficial (first degree) burn on the left wrist due to close proximity to the arc flash. Additionally, the electrician sustained a minor contusion on the back of the left hand from striking the combination motor starter panel door as a result of a reflex action from the arc flash.

The Facility Operations Division (FOD) Director immediately issued a timely order to staff that required all high- and medium-risk electrical work, including testing and diagnostics, be evaluated and approved by either the Facility Operations or Engineering Construction \& Design Division Manager or designee.

The FOD Director also chartered an investigation and causal analysis of the arc flash event. The investigation team under the leadership of a trained investigator was specifically chartered to identify causes and contributors to the event and recommend corrective actions to minimize the risk of recurrence. 


\subsection{Background}

\section{Work Activity}

The initiating condition for the work activity was the failure of CHWP \#2 to run when commanded by the METASYS automated facility control system. During diagnostics of the system, the operator noted that in addition to failure of CHWP \#2 to run when commanded, CHWP\#1 shut down when the breaker for CHWP\#2 was manually opened. The Power Operator and Building Engineer discussed the system conditions that evening and a Service Request was generated to troubleshoot and repair the combination motor starter for CHWP \#2.

The troubleshooting and repair work scope was approved on Friday, April 21, 2006, by the Building Engineer. The CHWP \#2 combination motor starter incorporates both motor control and disconnecting functions. An anomaly in the METASYS system control components was believed to be the most likely cause of failure of CHWP \#2 to operate normally. During performance of work scope prior to the arc flash, this belief was further supported when a failed control transformer was identified as the cause of the failure of CHWP \#2 to run. The potential existence of a configuration problem or mislabeled breaker was not considered at this time due to what is believed to be an organizational mindset that facility system control issues, such as was experienced with CHWP \#2, are generally related to METASYS software programming.

The complex nature of logic controls, which could produce the observed conditions, and the conclusion that the source of system malfunction was an electrical control problem was not challenged throughout the planning and approval of the troubleshooting and repair work scope. This was reinforced by the fact that the operator on duty identified the configuration issue on Thursday evening and follow on discussion with the Building Engineer and workers did not question the belief that it was a control problem with CHWP \#2.

Post-event inspection of the chilled water system components identified that labels for the breakers supplying power to CHWP \# 2 and CHWP \#1 were reversed.

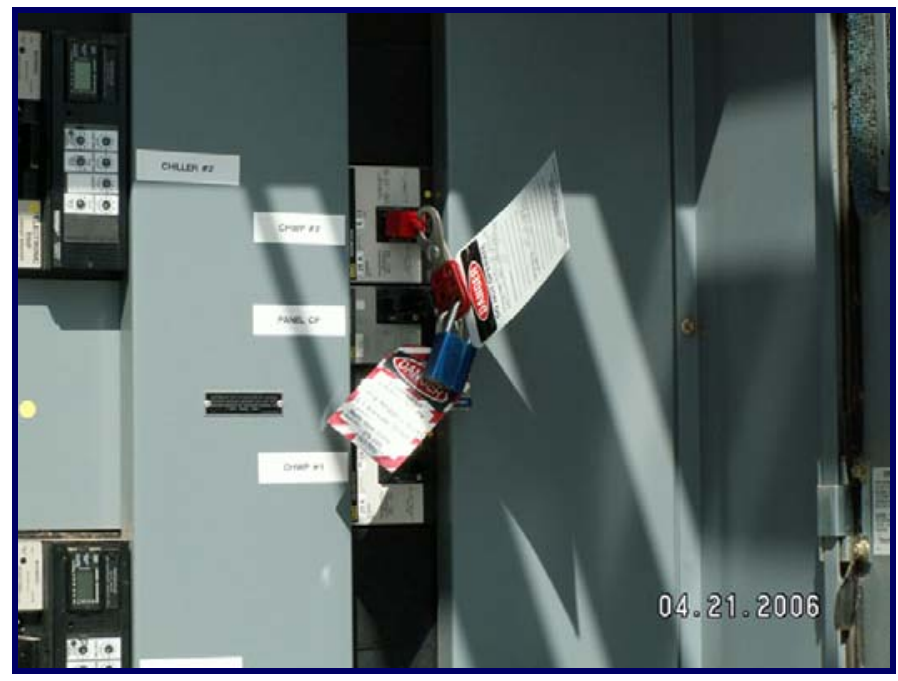

Figure 2.1. 331 Building, CHWP \#1 and \#2 Breaker, Labels 


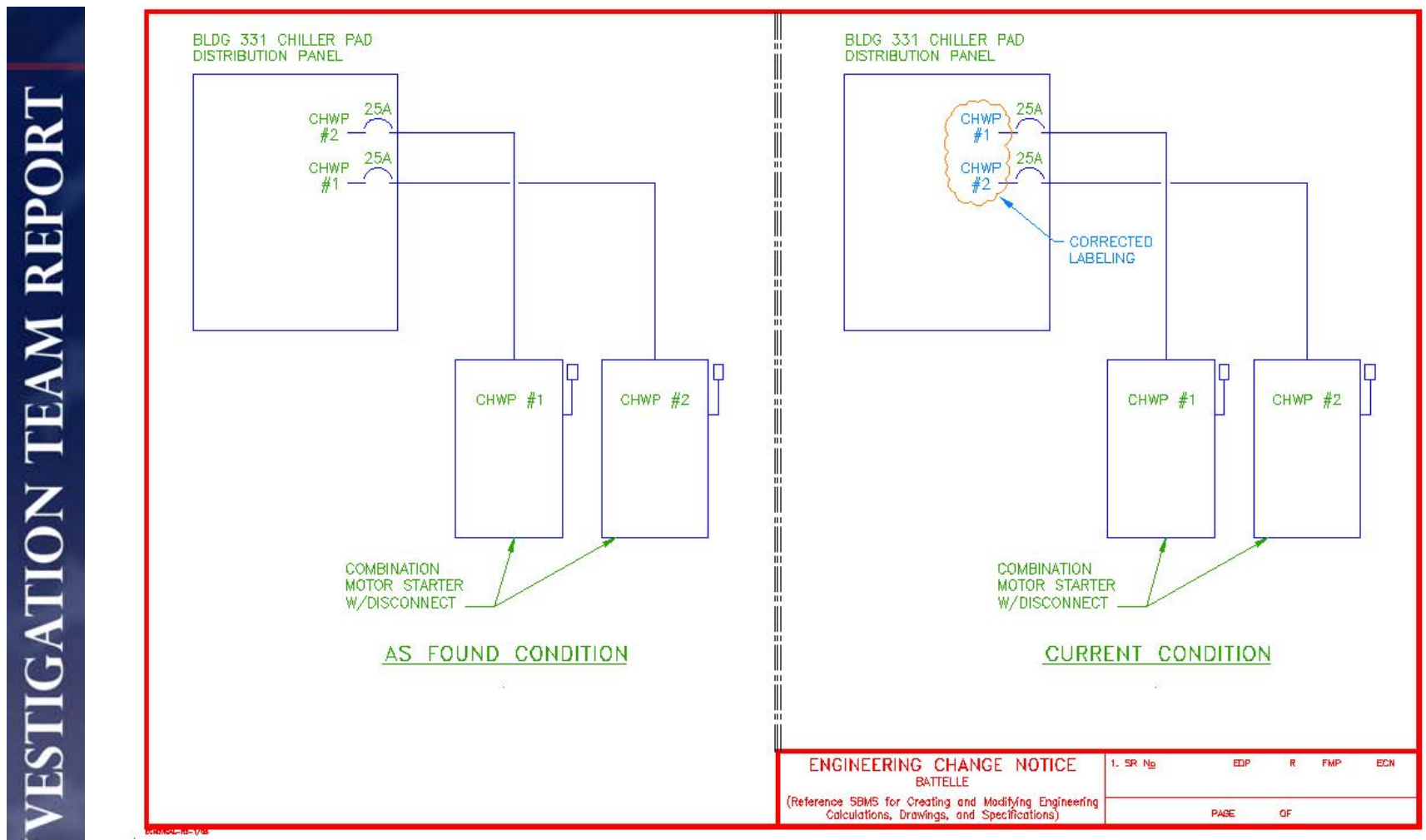

Figure 2.2. 331 Building, CHWP \#1 and \#2 Electrical Diagram

This labeling error dating from the time of system construction in the summer of 2000 contributed to incorrect system configuration and placement of LOTO on the wrong breaker.

The energized state of the combination motor starter due to the wrong system configuration was not detected during verification of de-energized state by the workers. The event investigation identified three credible failure modes for why the workers failed to detect the presence of electrical energy on the line side of the combination motor starter disconnect. Workers involved in the repair activity were aware of the electrical hazards associated with this type of work and took precautions, as identified in existing procedures, to create a safe work environment.

The workers performing the pump troubleshooting and repair performed a series of voltage measurements with the breaker labeled CHWP \#2 energized and de-energized prior to installation of LOTO. The Fluke model T-2 test meter indications were indicative of a deenergized state during the Safe-Condition and Safe-to-Work check determinations. The deenergized check of the combination motor starter disconnect line side failed to detect the presence of energy, leaving this portion of the combination motor starter energized during performance of the troubleshooting and repair work scope.

A factory provided arc suppressor, designed to prevent phase-to-phase arcing within the combination motor starter, was in place on the line side of the disconnect during the SafeCondition and Safe-to-Work checks. The design of the arc suppressor restricted access and visibility of the line side phase lugs in the combination motor starter. 
The Fluke model T-2 Meter used in this activity is subject to voluntary manufacturer's recall due to the potential for batteries in the tester becoming corroded and the meter becoming inoperable. The worker performed a meter challenge before and after the Safe-Condition and Safe-to-Work checks. The meter was also exhaustively tested during the course of this investigation and determined to be fully functional with no corrosion observed in the battery compartment.

The design of the Fluke model T-2 meter incorporates a probe holder in the meter housing which was used during this work to position one of the test probes for the Safe-Condition and Safe-toWork checks.

The following section describes credible scenarios for the worker's failure to detect energy.

The investigation team reviewed, in detail, the Safe-Condition and Safe-to-Work checks that were performed during this work. The purpose of the Safe-Condition check is to confirm the system configuration and isolation boundary. The PNNL LOTO program defines SafeCondition check as, "The comprehensive inspection or test of the isolating boundary performed for/by the Controlling Organization to confirm that the isolating boundary is controlled to prevent exposure from all sources of hazardous energy/material.” The Safe-to-Work check is required to be performed by the assigned worker to verify a safe condition prior to performing any work. The PNNL LOTO program defines Safe-to Work check as, "The inspection or test the authorized worker performs to confirm that no hazardous energy exists where they will perform servicing or maintenance. For electrical energy, this involves the use of test equipment by a qualified person.” In this work activity, the Safe-Condition and Safe-to Work checks were performed at the same time by the same worker, which is allowed by procedure. The investigation team identified three credible scenarios for an ineffective Safe-Condition and Safeto-Cork checks to occur during the performance of this work.

1. Use of the probe holder, on the Fluke model T-2 meter, to position the test probe could have resulted in failure of the probe to contact the phase lug.

If the probe was not positioned in the meter probe holder correctly or if the probe shifts position (slides back) in the holder as a result of contact with other conductors during previous checks, the probe may not reach far enough through the arc suppressor to make contact with the phase lug.
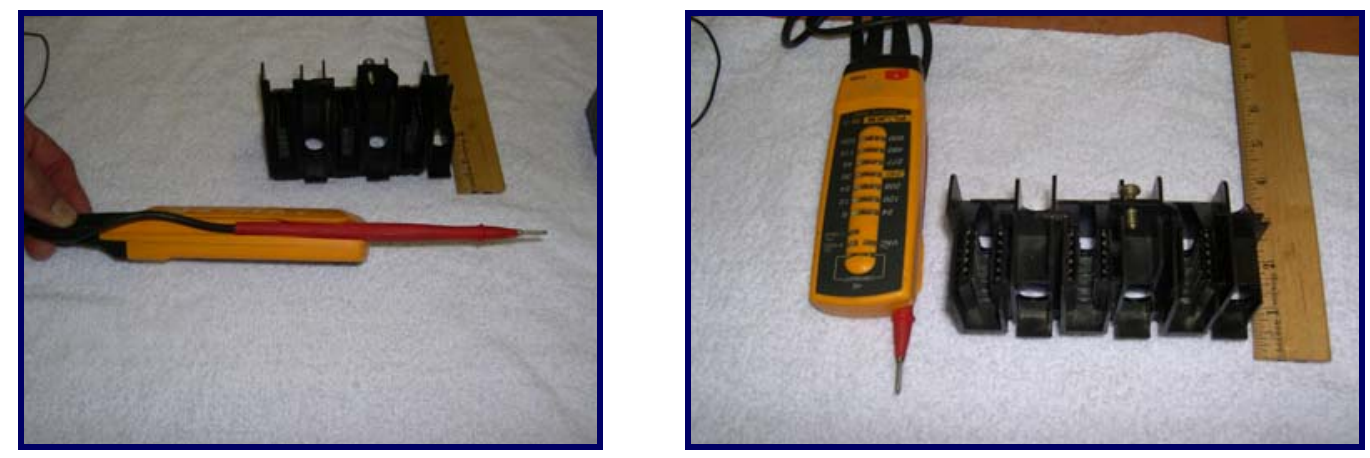

Figure 2.3. Fluke T-2 Meter with Probe in Housing 
2. The workers performing Safe-Condition and Safe-to Work checks could have mistaken contact with the arc suppressor as contact with the phase lug without any distinct indication from the Fluke model T-2 meter.

3. Corrosion on phase lugs could have resulted in inadequate contact between the meter probe and the lug without any distinct indication from the Fluke T-2 meter. During troubleshooting of the combination motor starter workers noted some corrosion on the phase lugs, which they treated with a spray on electrical cleaner. The investigation team concludes this is the least credible scenario due to the workers description of the observed corrosion.

The investigation team was not able to determine conclusively which of these scenarios was responsible for the ineffective Safe-Condition and Safe-to-Work check associated with this work.

\section{Building Chilled Water System History}

PNNL Project D487 replaced the main chiller system serving the 331 Building located in the 300 Area in the summer of 2000. The design for the project was performed by PNNL, with construction performed by Fluor Daniel Northwest, the Hanford Site Construction contractor. The Fluor Daniel Northwest construction forces that performed this work were very familiar with the 331 Building.

The new chillers were installed on the west side of the 331 Building. The project involved new pumping and control equipment and two 300-ton, air cooled, screw compressor type chillers.

As part of project scope, a new $750 \mathrm{KVA}$ transformer and switchboard were installed. Electrical power for the chillers and pumps is provided by the 300 Area power grid. Controls for the new equipment were installed and interfaced with the existing facility control system (METASYS) serving the 331 Building.

PNNL Project D487 construction was performed under a Cost Type Construction Contract and a formal acceptance test procedure (ATP) was not required or performed. A functional test was required by the PNNL Facility Modification Permit however, no supporting documentation was found in the project files.

PNNL performed a National Electric Code (NEC) inspection as part of the project but it did not require or include verification of correct breaker labeling. 


\subsection{Causal Factors}

\section{Direct Cause}

The Incorrect Breaker was De-Energized resulting in an Incorrect Isolation Boundary for CHWP \#2

Workers involved in performing the troubleshooting and repair of 331 Chilled Water Pump \#2 identified, de-energized, and applied Lock-out Tag-out (LOTO) to an incorrect breaker. Undetected reversal of the labeling for breakers CHWP \#1 and CHWP \#2 contributed to the incorrect system configuration.

\section{Root Causes}

The CHWP system breaker labeling error and resulting isolation of the incorrect breaker was not identified, as work progressed, due to a task performance error associated with the SafeCondition and Safe-to-Work Checks required by PNNL's Lock-out Tag-out (LOTO) and Electrical Safety programs.

\section{The CHWP \#1 and CHWP \#2 Breakers were Mislabeled}

A breaker labeling error occurred during construction of the 331 Chilled Water System.

a. This breaker labeling error was not identified during system commissioning and has existed until discovered on Sunday April 23, 2006, as part of the arc flash investigation activities.

b. There are no requirements to verify breaker labeling as part of system commissioning or maintenance.

c. A review of the chiller system modification and maintenance history did not produce any evidence to support the labeling error occurring after project completion.

\section{Task Performance Error, Failed Safe-Condition and Safe-to-Work Checks}

Qualified and experienced workers performed the Safe-Condition and Safe-to-Work checks in accordance with established requirements.

a. The energized state of the CHWP \#2 combination motor starter due to the wrong system configuration was not detected during verification of de-energized state by the workers.

b. The Safe-Condition and Safe-to-Work checks were performed at the same time in accordance with applicable procedures.

c. Three credible failure modes, involving contact of the Fluke model T-2 test probe with the line side phase lug, were identified that would support the Safe-Condition and Safeto-Work checks being ineffective in detecting electrical energy on the line-side of the disconnect. 


\section{Contributing Causes}

1. Procedures for Verification of Safe-Condition and Safe-to-Work Checks are Less Than Adequate (LTA)

Qualified and experienced workers performed the Safe-Condition and Safe-to-Work checks in accordance with established requirements that are consistent with industry practice.

a. The existing LOTO procedures allow the Safe-Condition and Safe-to-Work checks to be performed simultaneously by the same worker.

b. The LOTO and Electrical Safety procedures, as written, do not anticipate the SafeCondition and Safe-to-Work check failure scenarios identified during this investigation.

c. The LOTO and Electrical Safety procedures, as written, rely on skill of the electrical worker to perform Safe-Condition and Safe-to Work checks and do not provide specific guidance on the proper way to check 3-phase electrical systems.

2. The CHWP system configuration information was not identified or acted on as part of the planning or the troubleshooting and repair of CHWP \#2.

The system configuration discrepancy with CHWP \#1 and CHWP \#2 was noted and logged by operator log on Thursday April 20, 2006. The possibility of reversed breaker labeling was never identified as an explanation of the conditions noted by the operator.

a. The decision to troubleshoot and repair relied heavily on the premise that the issue was likely a facility control system problem with METASYS.

b. The work evolution identified failed control components further supporting the control issue theory.

c. Operations and maintenance staff often consider the automated facility control system (METASYS) to be responsible for operational issues that are not readily apparent. 


\subsection{Conclusions \& Recommendations}

The electrical workers performing the scope of work described in this report were aware of the electrical hazards involved and took precautions as identified in existing procedures to create a safe work environment. Incorrect breaker labeling and the ineffective Safe-Condition and Safeto-work checks resulted in the undetected presence of electrical energy during the performance of the work scope.

The importance of accurate and up-to-date system component labeling is critical to proper system configuration and performing work safely.

Verification of correct system isolation boundaries by effective LOTO Safe-Condition and Safeto-work checks is essential to mitigation of the risk created by labeling and wiring errors. The three credible scenarios identified for ineffective Safe-Condition and Safe-to-work checks dictate that additional precautions are necessary to verify contact is made between the test meter probe and the phase lug when Safe-Condition and Safe-to-Work checks involve arc suppressors or other objects that obscure visual observation.

\section{Recommendations:}

R1. Component labeling accuracy needs to be included as part of system commissioning for new or modified electrical systems. The engineering and operations procedures that address new or modified electrical systems need to be revised to include verification of correct component labeling and confirmation that the labeled isolation point correctly isolates the identified component.

R2. Electrical Safety and LOTO procedure requirements and training needs to be revised so that workers verify the electrically de-energized condition (Safe-Condition and Safe-to-Work Check) by observing the test meter probe contact with the component to be tested. These procedures should also incorporate the option, where appropriate, to allow for verification of the test meter probe contact by watching presence of electrical energy and the test meter indications falling when de-energized. Specific areas of existing procedures that need to be clarified or revised include

a. Allowance of the Safe-Condition and Safe-to-work checks by the same worker.

b. While not a contributor to this event, the term "known" systems in the LOTO procedure was identified as needing to be defined or eliminated. In one instance, the procedure for Safe-Condition check indicates that verification of zero energy by a qualified worker using test instruments is required as a final part of the check. The same procedure later indicates that a qualified worker check with a test instrument is not required for "known" systems.

c. Revise Course 1014, Electrical Safety, to include practical exercises, including performance of Safe-Condition and Safe-to-work checks.

R3. Develop a Lessons Learned that addresses the importance of equipment labeling accuracy and Safe-Condition, Safe-to-Work checks for Laboratory and DOE-wide distribution. 


\section{Opportunities for Improvement:}

O1. Verify the design procedures and process for new electrical systems and components incorporate consideration of human factors and worker safety.

O2. Assess using the NFPA 70E option of using arc flash calculations for work planning and determination of job specific PPE.

O3. Contact appropriate parties within National Electrical Manufacturers Association (NEMA) and or Underwriters Laboratories (UL) to share lessoned learned from this event, including the arc suppressor contribution to the failed Safe-to Work checks.

O4. As a result of the manufacturer's voluntary recall, immediately stop using all Fluke model T2 electrical test meters and remove them from the field.

O5. Conduct an assessment to determine and validate the appropriate types and quantities of electrical test meters, probes, and test leads are available at PNNL.

O6. Establish model and operating standards for all electrical test equipment at PNNL.

O7. Improve the PNNL equipment recall process to make sure manufacturers recalls are current and acted on immediately.

O8. Establish a process to review PPE suitability for use based on regulatory requirements and manufacturer recommendations.

O9. Incorporate the METASYS drawings into the list of PNNL key drawings. 


\section{Appendix A: Team Charter \& Team Members}

CHARTER - April 21, 2006; PNNL 331 Chiller Pad Arc Flash Event

A PNNL investigation team has been established to provide support to the Facility Operations Directorate regarding the recent serious arc flash maintenance accident involving the 331 Building chilled water system. The investigation team scope of work shall include performing a root cause analysis, developing corrective actions and related reporting.

The investigation team, consisting of Gary Swearingen -Team Leader and ten principal investigators is chartered to conduct a root cause analysis of the recent serious arc flash maintenance accident. The team is specifically directed to:

- Develop a detailed sequence of events related to the accident.

- Perform a root cause(s) analysis using a minimum two analytical techniques. The investigation team leader will select the appropriate techniques from Fault Tree Analysis, Hazard-Barrier-Target Analysis, Change Analysis, and MORT Analysis (specific sections as applicable).

- Prepare a brief daily progress update when requested by the FOD Division Director.

- Identify and communicate immediately any related potential compensatory measures or lessons learned that are identified by the team regardless of specific relationship to cause of this event.

- Identify the causes and contributors to the serious arc flash maintenance accident.

- Develop and recommend corrective actions to minimize the risk of recurrence.

- Provide the FOD Director with a summary of the findings of their investigation in a format approved by the FOD Director.

The investigation team shall present an oral briefing to the appropriate PNNL and PNSO management with respect to the final report of the team.

When conducting interviews, the team shall inform the interviewee that the interview is part of the PNNL investigation into the serious arc flash maintenance accident and that any information they provide can be used to support the investigation. The team shall focus on systemic and programmatic concerns attributable to cause of the accident. The investigation team may employ additional specific subject matter expertise and consultation as approved by the FOD Director that is necessary to support the assessment scope.

The investigation team is authorized to spend up to two weeks working on gathering information and performing the related analysis. At the end of this time (May 5th), the team is expected to have submitted their draft written report with findings and recommendations to FOD Management for internal review. The final report is to be completed prior to May $12^{\text {th }}$ 2006.

Larry E Maples, FOD Director

Date 


\section{Appendix A: Team Charter \& Team Members (cont.)}

Team Members:

Gary Swearingen

Mark Deichman

John Drewrey

Hurtis Hodges

Vern Madson

Allen Minton

Dan Montgomery

Marv Olson

Pete Rojas

Sanjay Sanan

Reed Sharp

Bobby Sparks
Investigation Team Lead

Construction Safety Specialist

Journeyman Electrician, Union Steward

Maintenance and Fabrication Services Manager

Union Safety Representative, VPP Committee Chairman

Electrical Engineer

Facility Operations Division, Facility Management Systems Manager

Chief Engineer

North Work Center Manager

Building Engineer

Facility Operations Technical Operations and Assurance

Electrical Safety Subject Matter Expert 


\section{Appendix B: Methodology}

A PNNL multidisciplinary investigation team was assembled and lead by a PNNL staff member with broad experience in accident investigation and analyses of events of similar significance within the DOE and other agencies. Initial data was gathered via event site visits, employee interviews and document reviews. Once an initial basis for understanding the event was established, the investigation team employed recognized event investigation and causal factors identification techniques including Change Analysis, Hazard-Barrier-Target Analysis, and Management and Oversight Risk Tree (MORT) analyses to identify specific causes and areas of interest in regard to this event. The conclusions of these analyses were used to develop the causal factors and recommendations described in this report.

Internal Peer Review: Once the event report draft including causal factors and recommendations was complete, a separate, internal PNNL review team was assembled to assess the draft analysis at a briefing provided by the investigation team. The internal review team included individuals with electrical engineering, industrial health and Safety, laboratory training, event investigation, and causal analysis expertise.

\section{Internal Review Team Members:}

Scott Allen

Harold Bowers

Doug Larsen

Doug Falk

Steve Cooke

Dennis Walters
FOD Technical Operations \& Assurance

PNNL Training and Qualification

Electrical Engineer

Worker Safety and Heath

PNNL Legal

Independent Oversight 


\section{Appendix C: Interviews Conducted}

Electricians (4)

Power Operators (4)

Work Team Leads (2)

Work Center Manager (1)

Building Manager (1)

Building Engineer (1)

PNNL SME- Lock Out Tag Out (1)

PNNL SME- Electrical Safety (1)

External SME-Electrical Standards \& Practices (1) 


\section{Appendix D: Event Timeline}

\section{FY-2000 System Installed}

No work evolutions identified prior to 4/20/06 which would have required work on line sides of disconnect.

\begin{tabular}{|c|c|}
\hline $17: 28$ & $\begin{array}{l}\text { Power Operator } 1 \text { Log entry - "a Service Request has been submitted for further } \\
\text { processing to repair/troubleshoot } 600 \text { ton chiller pump \#2. The Service Request } \\
\text { number is S558539." }\end{array}$ \\
\hline 18:00 & $\begin{array}{l}\text { Power Operator } 1 \text { Log entry - " } 600 \text { ton Chiller Pump \#2 failed, notified BE (Building } \\
\text { Engineer) as required, and lock and tagged out of service. When the breaker to the } \\
\# 2 \text { pump was opened, the } \# 1 \text { pump/chiller shut down. Alarms from the wet lab started } \\
\text { to come in, when the breaker to the \#2 pump was closed the \#1 pump/chiller came } \\
\text { back on line? To facilitate wet lab requirements the } 200 \text { ton chiller was utilized by } \\
\text { setting the chiller system to all chillers RUN. While the breaker to \#2 chilled water } \\
\text { pump was open, the Point CHILL-LL was flashing back and forth between \#1 and \#2 } \\
\text { chiller. An attempt to SWO (soft ware override) this point to \#1 chiller did not allow the } \\
\text { chiller to stay running with the breaker to the \#2 pump opened as we tested. The BE } \\
\text { was notified as required." Note: Power Operator } 1 \text { reported in interviews that the lock } \\
\text { and tag mentioned in the beginning of this log entry was prepared but never installed } \\
\text { due to the need to close breaker CHWP\#2 as described in later portions of the log } \\
\text { entry. }\end{array}$ \\
\hline \multicolumn{2}{|c|}{$4 / 21 / 06$} \\
\hline 06:34 & $\begin{array}{l}\text { Service request } \mathbf{S 5 8 5 3 9} \text { was triaged as Planned Work in anticipation of the need to } \\
\text { order parts once initial troubleshooting could be done to identify the problem. Formal } \\
\text { planning to develop a Job Planning Package was not needed. }\end{array}$ \\
\hline 07:00 & $\begin{array}{l}\text { Plan Of the Day (POD) meeting was held. The work activity was formally released for } \\
\text { work. The Service Request was listed on the approved POD. }\end{array}$ \\
\hline 07:30 & $\begin{array}{l}\text { Following the POD the Work Team Lead for Government } 1 \text { Team held a meeting in } \\
331 \text { Building Room } 2 \text {. The purpose was to discuss work authorized for the day and } \\
\text { assign electricians. Elements of Dispatch Ready To Work Checklist (pre-job briefing) } \\
\text { were discussed (i.e. scope of work, electrical hazard and hazardous energy controls) } \\
\text { with assigned electricians at close of meeting. }\end{array}$ \\
\hline 08:15 & Electrician 1 and 2 go to 350 Building to coordinate with Power Operator 2. \\
\hline 08:25 & $\begin{array}{l}\text { Electricians spoke to Power Operator } 2 \text { by phone. Returned to } 331 \text {. } \\
\text { While waiting, Electrician } 1 \text { and } 2 \text { reviewed the Service Request, walked down system, } \\
\text { got PPE, observed that the disconnect switch in the combination motor starter for } \\
\text { CHWP \#2 was off. Electrician } 2 \text { calls Power Operator } 2 \text { again. }\end{array}$ \\
\hline
\end{tabular}

08:30-09:00

Power Operator 2 arrives at work site. They walk down site, identify breaker labeled for CHWP\#2, in power distribution panel that feeds combination motor starter for CHWP\#2. They talk about system configuration and discuss perceived control problems and symptoms observed by Power Operator 1.

Electricians ask Power Operator 2 if he wants to apply Controlling Organization Do Not Operatate (DNO) lock out tag out (LOTO) on breaker labeled CHWP\#2. The answer is no. The electricians can apply personal LOTOs and control operation of breaker for CHWP\#2 in the power distribution panel. 


\begin{tabular}{|c|c|}
\hline \multirow[t]{6}{*}{$\sim 09: 30$} & $\begin{array}{l}\text { Electrician } 1 \text { and } 2 \text { remove jewelry and don PPE. } \\
\text { Electrician } 1 \text { and } 2 \text { energize disconnect switch in the combination motor starter for } \\
\text { CHWP\#2 to verify source of power. The door to the combination motor starter is } \\
\text { closed. } \\
\text { Electrician } 1 \text { overrides door-stop on the combination motor starter and places probe } \\
\text { in meter housing slide, Electrician } 2 \text { holding door. } \\
\text { Safe Condition and Safe To Work Check starts-with system energized to verify } \\
\text { source of power, working from top to bottom on disconnect in combination motor } \\
\text { starter, taking line-side readings through the arc suppressor. Electrician } 1 \\
\text { measures voltages phase to phase and phase to ground. Reads voltages seen to } \\
\text { electrician } 2 \text {. } \\
\text { Safe Condition and Safe to Work Checks continue, Electrician } 1 \text { checks on the load- } \\
\text { side of disconnect pump \#2. } \\
\text { Electrician } 1 \text { tested the top side of the mag starter and } 2 \text { associated fuse holders. } \\
\text { Electrician } 1 \text { checked top of control transformer then bottom of control transformer- } \\
\text { observed } 24 V \text { on output of the transformer. Electrician } 1 \text { observes corrosion on } \\
\text { some components and small amount of water present in the bottom of the cabinet } \\
\text { and decides not to take further readings in the lower section of the enclosure. } \\
\text { Electricians } 1 \text { and } 2 \text { are satisfied that power to the combination motor starter had } \\
\text { been verified. } \\
\text { Electrician } 1 \text { walks to power distribution panel that feeds the combination motor } \\
\text { starter for CHWP\#2, opens breaker labeled CHWP\#2. Electrician } 1 \text { applies } \\
\text { personal LOTO, while electrician } 2 \text { guards door to the combination motor starter for } \\
\text { CHWP\#2. } \\
\text { Electrician } 1 \text { walks back to combination motor starter for CHWP\#2, checks for } \\
\text { power on line-side of disconnect in the combination motor starter for CHWP\#2 } \\
\text { through manufacturer installed arc suppressor. Electrician } 1 \text { checked A phase to B, } \\
\text { A to C, and A to ground. Found no indication of power. Note: The Team has } \\
\text { concluded that inadequate contact between the test meter and A phase conductors } \\
\text { in this step resulted in failure of electrician } 1 \text { to detect presence of energy on this } \\
\text { part of the combination motor starter assembly. }\end{array}$ \\
\hline & $\begin{array}{l}\text { Safe Condition and Safe to Work Checks on line-side of disconnect in combination } \\
\text { motor starter are complete. } \\
\text { Electrician } 1 \text { opens disconnect switch on combination motor starter, watches knife } \\
\text { switches open, takes readings, phase-phase-phase ground on load side of } \\
\text { disconnect, no power observed. Electricians believe Safe Condition and Safe to } \\
\text { Work Checks are complete. }\end{array}$ \\
\hline & $\begin{array}{l}\text { Electricians discuss perceived results of voltage measurements to establish safe } \\
\text { work conditions and remove PPE. }\end{array}$ \\
\hline & $\begin{array}{l}\text { Electrician } 2 \text { then goes to distribution panel to apply personal LOTO to breaker } \\
\text { labeled CHWP\#2. }\end{array}$ \\
\hline & $\begin{array}{l}\text { Work in the combination motor starter begins. Electrician } 2 \text { hands tools to } \\
\text { Electrician } 1 \text { due to limited size of the enclosure. Cleaning of corrosion begins. } \\
\text { Electricians remove and clean load-side conductors. }\end{array}$ \\
\hline & $\begin{array}{l}\text { Government Team } 1 \text { Work Team Lead arrives while cleaning is underway. The } \\
\text { Work Team Lead asks if Safe Conditon, Safe to Work Checks and LOTO are } \\
\text { complete. Electricians respond in the affirmative. }\end{array}$ \\
\hline
\end{tabular}




\section{Appendix D: Event Timeline (cont.)}

\begin{tabular}{|c|c|}
\hline & $\begin{array}{l}\text { Electricians describe conditions observed in the combination motor starter enclosure, } \\
\text { (i.e., water in the bottom, corrosion on some components) to the Work Team Lead. } \\
\text { Work Team Lead leaves. }\end{array}$ \\
\hline & $\begin{array}{l}\text { Electricians drill small hole in bottom of the enclosure to prevent future collection of } \\
\text { water. }\end{array}$ \\
\hline & $\begin{array}{l}\text { Electricians remove arc suppressor on the line-side of the disconnect switch to clean } \\
\text { corrosion with an electrically safe aerosol product intended for this purpose. }\end{array}$ \\
\hline 10:00 & $\begin{array}{l}\text { Electricians go to } 350 \text { Building for break. They collect sealant (RTV) to seal "Meyers } \\
\text { Hub" that appears to have allowed water into the combination motor starter. }\end{array}$ \\
\hline \multirow[t]{2}{*}{$10: 20$} & $\begin{array}{l}\text { Electricians Return to 331, wiped off Meyers hub, applied RTV - checked fuses, found } \\
\text { them good. }\end{array}$ \\
\hline & $\begin{array}{l}\text { Electricians Pull heaters, find them corroded. Electricians clean and reinstall heaters. } \\
\text { Electricians examine reset switch on exterior of the combination Motor starter. It is } \\
\text { sticking. The switch is cleaned and freed. Heaters are reset and verified set. }\end{array}$ \\
\hline 10:30-11:00 & $\begin{array}{l}\text { Electricians determine that a control power transformer has failed and needs } \\
\text { replacement. In order to remove the transformer, the mounting plate holding the } \\
\text { transformer and other components must be loosened and repositioned. The } \\
\text { transformer is removed. }\end{array}$ \\
\hline $11: 20$ & $\begin{array}{l}\text { Electrician } 1 \text { prepares to leave for the day. Electricians discuss the potential need for } \\
\text { the Controlling Organization to install a DNO tag for long term configuration control if } \\
\text { replacement parts are unavailable and must be ordered. Power Operator } 2 \text { is } \\
\text { contacted and Installs a Controlling Organization DNO LOTO over the Electricians' } \\
\text { personal LOTO for configuration control in the event the system cannot be restored to } \\
\text { service at the end of the day. Electrician } 1 \text { removes his personal LOTO as he is } \\
\text { leaving for the day, Electrician } 2 \text { and Controlling Organization DNO LOTOs remain in } \\
\text { place. }\end{array}$ \\
\hline
\end{tabular}




\section{Appendix D: Event Timeline (cont.)}

\begin{tabular}{|c|c|}
\hline$\sim 12: 00$ & Electrician 2 goes to 350 Building for lunch and to obtain a new transformer. \\
\hline & $\begin{array}{l}\text { Electrician } 2 \text { eats lunch, briefs the Work Team Lead on progress. A replacement } \\
\text { transformer is located. }\end{array}$ \\
\hline$-12: 30$ & Electrician 2 Goes back to 331 and begins re-installation of components. \\
\hline$-13: 20$ & $\begin{array}{l}\text { While repositioning the mounting plate with the new transformer installed, Electrician } 2 \\
\text { hears/feels heat from a suspected arc but is unsure what had happened. Electrician } 2 \\
\text { goes to the distribution panel and observes that breaker CHWP\#1 is now open. } \\
\text { Electrician } 2 \text { puts on PPE that had been used in original Safe Condition and Safe to } \\
\text { Work Checks, and begins to look for source of power. Electrician } 2 \text { observes C phase } \\
\text { conductor on line-side of the combination starter disconnect switch is loose and may } \\
\text { have contacted B phase while the mounting plate was being repositioned. }\end{array}$ \\
\hline$\sim 13: 30$ & $\begin{array}{l}\text { Electrician } 2 \text { informs Work Team Lead that some sort of arc flash had just occurred. } \\
\text { Electrician } 2 \text { states that he is uninjured and that he did not feel a shock. There is some } \\
\text { soot on his left hand. }\end{array}$ \\
\hline $13: 45$ & Work Team Lead notifies Work Center Manager \\
\hline $13: 50$ & Work Center Manager notifies Building Manager \\
\hline$-14: 00$ & Actions are underway to secure the event scene and document conditions. \\
\hline $14: 00$ & Maintenance and Fabrication Services Manager notified. \\
\hline $14: 00$ & $\begin{array}{l}\text { Power Operator } 2 \text { log entry - Controlling Organization DNO LOTO applied to CHWP } \\
\# 1 \text { as a precaution due to unknown source of power in combination starter for } \\
\text { CHWP\#2. Power Operator \#2 had installed a Controlling Organization DNO LOTO } \\
\text { over the Electricians' Personal LOTOs on CHWP\#2 before lunch. }\end{array}$ \\
\hline $14: 25$ & Work Team Lead notifies PNNLs' Operations Center of the event. \\
\hline $14: 35$ & $\begin{array}{l}\text { Work Team Lead transports Electrician } 2 \text { to site medical services provider for } \\
\text { evaluation. }\end{array}$ \\
\hline$\sim 15: 29$ & Initial event classification made - Group 10 (3) SC 3 - Management Concern. \\
\hline$\sim 15: 30$ & FOD Director appoints an experienced Investigation Team Lead \\
\hline
\end{tabular}




\begin{tabular}{|c|c|}
\hline $15: 40$ & $\begin{array}{l}\text { Site medical services provider completes evaluation of electrician } 2 \text {. First aid was } \\
\text { administered on a light/minor (1st degree) burn and a contusion to the left hand. } \\
\text { Electrician } 2 \text { was released to return to work no restrictions. }\end{array}$ \\
\hline $16: 45$ & $\begin{array}{l}\text { Based on additional information, the event was upgraded to an SC- } 2 \text { event and a } \\
\text { classification criteria of Hazardous Energy Control, (1) SC-2 was added to the original } \\
\text { classification. }\end{array}$ \\
\hline 18:30 & $\begin{array}{l}\text { A Work Control Standing Order was issued to elevate approval of all medium and high } \\
\text { risk electrical work activities as defined in PNNLs Electrical Safety Subject Area. ( }<50 \\
\vee \text { and }<1000 \mathrm{~W},<10 \mathrm{~J} \text { stored energy or }>50 \mathrm{~V} \text { and }<5 \mathrm{~mA},<10 \mathrm{~J} \text { stored energy) to the } \\
\text { Facility Operations Division Director. }\end{array}$ \\
\hline
\end{tabular}


Appendix E: Barriers Analysis

\begin{tabular}{|c|c|c|c|c|c|}
\hline Barrier & $\begin{array}{l}\text { Did Not } \\
\text { Provide }\end{array}$ & $\begin{array}{l}\text { Did } \\
\text { Not } \\
\text { Use }\end{array}$ & Failed & $\begin{array}{l}\text { Did } \\
\text { Not } \\
\text { Fail }\end{array}$ & Evaluation For Comments \\
\hline $\begin{array}{l}\text { Hazard } \\
\text { Control } \\
\text { /LOTO } \\
\text { Program/ } \\
\text { LOTO Point } \\
\text { Verification }\end{array}$ & & & $\mathrm{X}$ & & $\begin{array}{l}\text { LOTO Failed - Misapplied, was applied to } \\
\text { the wrong breaker as a result of mis- } \\
\text { labeling }\end{array}$ \\
\hline $\begin{array}{l}\text { CWP Breaker } \\
\text { Labeling }\end{array}$ & & & $\mathrm{X}$ & & $\begin{array}{l}\text { CWP Breakers were confirmed as } \\
\text { mislabeled }\end{array}$ \\
\hline $\begin{array}{l}\text { Adequacy of } \\
\text { Training } \\
\text { Curriculum } \\
\text { 1014/LOTO }\end{array}$ & & & $\mathrm{X}$ & & $\begin{array}{l}\text { Less than adequate - Training curriculum } \\
\text { did not anticipate failure as observed in the } \\
\text { event. Training did include appropriate } \\
\text { guidance for the procedures that it was } \\
\text { created to address. (see procedures below) }\end{array}$ \\
\hline $\begin{array}{l}\text { Safe To Work } \\
\text { Check/Safe } \\
\text { Condition } \\
\text { check }\end{array}$ & & & $X$ & & $\begin{array}{l}\text { Conducted concurrently, both failed to } \\
\text { detect energized } 480 \text { volt power. }\end{array}$ \\
\hline $\begin{array}{l}\text { Worker } \\
\text { Application } \\
\text { of Fluke T2 } \\
\text { Electrical } \\
\text { Test Meter }\end{array}$ & & & $\mathrm{X}$ & & $\begin{array}{l}\text { Task performance error highly probable } \\
\text { resulting in qualified worker failing to } \\
\text { have meter probe tip contact energized } \\
\text { components }\end{array}$ \\
\hline $\begin{array}{l}\text { Square D } \\
\text { ARC } \\
\text { Suppressor }\end{array}$ & & & & $\mathrm{X}$ & $\begin{array}{l}\text { Suppressor did not fail in performing its } \\
\text { intended function. However, human } \\
\text { interface issues and arc suppressor design } \\
\text { may have contributed to qualified } \\
\text { worker's inability to detect hazard. }\end{array}$ \\
\hline $\begin{array}{l}\text { Personal } \\
\text { Protective } \\
\text { Equipment } \\
\text { (PPE) }\end{array}$ & & & & $\mathrm{X}$ & $\begin{array}{l}\text { PPE did not fail in its intended function. } \\
\text { However, human interface issues, such as } \\
\text { potential impaired visual and tactile } \\
\text { impairment. }\end{array}$ \\
\hline $\begin{array}{l}\text { Pre-Job } \\
\text { Briefing }\end{array}$ & & & & $\mathrm{X}$ & $\begin{array}{l}\text { Briefing was adequate in content per } \\
\text { procedures }\end{array}$ \\
\hline
\end{tabular}




\begin{tabular}{|c|c|c|c|c|c|}
\hline \multicolumn{6}{|c|}{ Appendix E: Barriers Analysis (cont.) } \\
\hline Barrier & $\begin{array}{l}\text { Did Not } \\
\text { Provide }\end{array}$ & $\begin{array}{l}\text { Did } \\
\text { Not } \\
\text { Use }\end{array}$ & Failed & $\begin{array}{l}\text { Did } \\
\text { Not } \\
\text { Fail }\end{array}$ & Evaluation For Comments \\
\hline $\begin{array}{l}\text { Effective } \\
\text { Communicati } \\
\text { on between } \\
\text { involved } \\
\text { workers; } \\
\text { Conduct of } \\
\text { Operations - } \\
\text { adequate } \\
\text { information } \\
\text { sharing }\end{array}$ & & & $\mathrm{X}$ & & $\begin{array}{l}\text { Involved workers met at the job site and } \\
\text { discussed system configuration and } \\
\text { system control anomalies observed by } \\
\text { the Power Operator. Workers proceeded } \\
\text { with troubleshooting and repair - did not } \\
\text { consider the potential of a mislabeled } \\
\text { breaker to explain perceived control } \\
\text { problems. }\end{array}$ \\
\hline $\begin{array}{l}\text { Hazard } \\
\text { Analysis }\end{array}$ & & & & $\mathrm{X}$ & $\begin{array}{l}\text { Involved staff correctly identified the } \\
\text { electrical hazards posed by a } 480 \text { Volt } \\
\text { system, took precautions as described in } \\
\text { existing procedures, Control of the } \\
\text { hazard was ineffective due to a labeling } \\
\text { error. }\end{array}$ \\
\hline $\begin{array}{l}\text { Plan Of Day/ } \\
\text { Work Release }\end{array}$ & & & & $\mathrm{X}$ & $\begin{array}{l}\text { Activity was on the approved POD \& } \\
\text { discussed }\end{array}$ \\
\hline Drawing & & $\mathrm{X}$ & & & $\begin{array}{l}\text { The job met dispatch work criteria and } \\
\text { no design drawing was utilized in the } \\
\text { conduct of the work. Since the job was } \\
\text { walked down and equipment clearly } \\
\text { visible, the use of a drawing would not } \\
\text { be expected for this maintenance/ } \\
\text { troubleshooting effort. }\end{array}$ \\
\hline $\begin{array}{l}\text { Acceptance } \\
\text { Testing }\end{array}$ & & & $\mathrm{X}$ & & $\begin{array}{l}\text { LTA-Acceptance Test process not robust } \\
\text { enough to identify labeling accuracy. }\end{array}$ \\
\hline $\begin{array}{l}\text { Inspection } \\
\text { (Initial) NEC }\end{array}$ & & & & $\mathrm{X}$ & Not expected to ID switched labels \\
\hline $\begin{array}{l}\text { Commissioni } \\
\text { ng Process w/ } \\
\text { ATP }\end{array}$ & & & $\mathrm{X}$ & & See ATP discussion above. \\
\hline $\begin{array}{l}\text { Functionality } \\
\text { Test of Fluke } \\
\text { T2 Meter }\end{array}$ & & & & $\mathrm{X}$ & $\begin{array}{l}\text { The Fluke T2 meter functionality tests } \\
\text { results were positive. The testing was } \\
\text { performed a number of times and at } \\
\text { different intervals. The testing results } \\
\text { indicate that the recall data obtained on } \\
\text { the involved T2 meter did not contribute } \\
\text { to the event. }\end{array}$ \\
\hline
\end{tabular}

